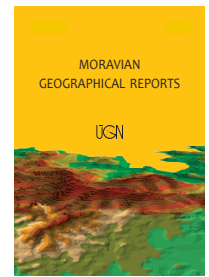

MORAVIAN GEOGRAPHICAL REPORTS

\title{
Business models in urban farming: A comparative analysis of case studies from Spain, Italy and Germany
}

\author{
Bernd PÖLLING ${ }^{\text {a }}$, María-José PRADOS ${ }^{\text {b * }}$, Bianca Maria TORQUATI c , Giulia GIACCHÈ d, \\ Xavier RECASENS ${ }^{\text {e }}$, Chiara PAFFARINI ${ }^{c}$, Oscar ALFRANCA ${ }^{\mathrm{e}}$, Wolf LORLEBERG ${ }^{\text {a }}$
}

\begin{abstract}
The "Urban Agriculture Europe" EU COST-Action (2012-2016) has shown that the complexity of urban agriculture (UA) is hardly compressible into classic business management models and has proposed new management models, such as the Business Model Canvas (BMC). Business models of UA have to be different from rural ones. In particular, factors such as differentiation and diversification, but also low cost-oriented specialisation, are characteristic and necessary business models for UA to stay profitable in the long term under challenging city conditions. This paper aims to highlight how farm enterprises have to adjust to urban conditions by stepping into appropriate business models aiming to stay competitive and profitable, and how the BMC is useful to analyse their organisation and performance, both economically and socially. The paper offers an inter-regional analysis of UA enterprises located in Spain, Italy, and Germany, which are further subdivided into: local food, leisure, educational, social, therapeutic, agri-environmental, cultural heritage and experimental farms. The analysis demonstrates that UA is differentially adjusted to specific urban conditions and that the BMC is useful for analysing urban farming. Heterogeneous local food farms and the integration of local and organic food production in social farming business models are most frequent in our case studies.
\end{abstract}

Keywords: entrepreneurship, urban farming, low-cost specialisation, diversification, differentiation, social farms, Spain, Italy, Germany

Article history: Received 14 October 2016; Accepted 2 June 2017; Published 30 September 2017

\section{Introduction}

Agriculture and cities have always been closely interwoven, and yet are often seen as contradictions. This relationship is reciprocal: (1) food supply to citizens; and (2) recycling of urban organic matter (Antrop, 2005; Ferguson, 2014; Zasada et al., 2013). The rural-oriented agri-food system, improved agricultural engineering, reduced transport costs and the globalisation of markets have truncated long-established links between the city and its agricultural neighbourhood. Today, agricultural areas in densely populated areas are fragmented due to changed economic models, population growth and urban encroachment (Yokohari et al., 1994). Farming in and around cities is also strongly influenced by the urban sphere (Heimlich and Barnard, 1992). Urban farming consists of commercial farming activities in metropolitan areas and is part of the wider urban agriculture umbrella, which includes - apart from professional urban farming also mushrooming non-profit oriented urban gardening initiatives of citizens (Lohrberg and Timpe, 2011; Lovell, 2010). Urban farming cultivates considerably large areas within agglomerations (Brinkley, 2012; Lohrberg, 2010; Lohrberg, 2011; Zasada, 2011). It is located in (intra-urban) and at the fringe (peri-urban) of cities, but the peri-urban transition zone is of the highest relevance (Lovell, 2010; Mougeot, 1999; Piorr et al., 2011; Opitz et al., 2016).

The advantageous as well as the disadvantageous influences of cities support and challenge urban farming in many different ways. Farms can give up or turn into part-time farming ventures with their main revenues

\footnotetext{
${ }^{\text {a }}$ Department of Agriculture in Soest, South-Westphalia University of Applied Sciences, Germany

b Department of Human Geography, University of Seville, Sevilla, Spain, (*corresponding author, e-mail: mjprados@us.es)

${ }^{\mathrm{c}}$ Department of Agricultural, Food and Environmental Sciences, University of Perugia, Perugia, Italy

d Mixed Research Unit Spaces and Societies, University of Rennes, Rennes, France

${ }^{\mathrm{e}}$ Departament d'Enginyeria Agroalimentària i Biotecnologia, Universitat Politècnica de Catalunya, Castelldefels, Spain
} 
originating outside of agriculture, or they can adjust their business towards urban demands in order to increase their chances of maintaining economic viability (FAO, 2007). Economies of scale dominate in rural areas by following the simplified principle 'growing or giving way'. This is due, with few exceptions, to urban limitations not the business case for urban farms. The complexity of urban influences on farms and farming results in heterogeneous strategies and farm activities both at the city and agglomeration level, which is more pronounced than in rather rural areas (Brinkley, 2012; Busck et al., 2006; Gardner, 1994; Mougeot, 1999; Zasada, 2011; Zasada et al., 2011). Urban farming "has been identified as being more diversified, polarised and multifaceted than elsewhere" (Zasada, 2011, p. 640). The nearness to cities creates opportunities for these urban farms. Undoubtedly, the city means greater demand for goods and services that can be offered by urban farmers. High-value production, niche products, marketing strategies apart from global markets, as well as the provision of various services linked to agricultural production, are commonly-used farm activities to adapt to and profit from cities (Bryant et al., 2013; Gardner, 1994; Heimlich and Barnard, 1992; Houston, 2005).

Gardner (1994) named firstly, higher added value production and, secondly, diversification towards services, as two characteristic farm adaptations for metropolitan farmers. He refers back to observations and explanations on farming intensity described by von Thünen as early as 1826 and on bid rent theory by Alonso (1964). Additionally, market strategies outside of traditional long food value chains, especially of fresh, non-mainstream and also processed products, are relevant in urban farming. Diversification strategies include a wide range of nonagricultural activities, yet often more or less loosely linked to primary agricultural production, such as tourism, recreation, leisure, education, health, cultural and natural activities (Buciega et al., 2009; Zasada, 2011). Cities and agglomerations enforce farm business adaptations to make profit out of the urban sphere. These city-adjusted farm activities build the key elements of characteristic business models of urban farming.

This paper aims to highlight how farm enterprises have adjusted to urban conditions by adopting appropriate business models aiming to stay competitive and profitable, and how the Business Canvas Model is useful in analysing their organisation and performances, both economically and socially. The paper offers an inter-regional analysis of UA farm enterprises located in Spain, Italy and Germany, which are further subdivided into specialised, differentiated and diversified farms (van der Schans, 2010, 2015; van der
Schans et al., 2016). This inter-regional approach between European countries allows for the detection of consistent and inconsistent business strategies and models applied under urban conditions - independently from other external determinants. This paper's theoretical framework is developed in the next section, followed by a description of the material and methods, the presentation of results, and final conclusions.

\section{Theoretical framework}

\subsection{Urban farming's business models}

"The business model explains how value is created for the customers and how value is captured for the company and its stakeholders" (Henriksen et al., 2012, p. 31). In the literature, the concepts of business models to set and analyse businesses arose in the mid-1990s (Henriksen et al., 2012). Many different definitions and interpretations of business models are in use; nonetheless, a common understanding of business models is obvious.

"It is thus widely accepted that the business model concept is emerging as a new unit in analysis, that business models emphasise on a system-level a holistic approach towards explaining how firms do business, that organisational activities play an important role in the various conceptualisations of business models, and that business models seek to explain how value is created and captured" (Henriksen et al., 2012, p. 32).

Based on, firstly, characteristic city-adjusted farm activities and, secondly, the business model method, some scholars have recently started to develop classifications of urban farming's business models (see Tab. 1).

Some years ago, van der Schans (2010) defined 'lowcost specialisation', 'differentiation' and 'diversification' as common business models of urban farming in the Netherlands; however, this also represented European conditions. Hereafter, we focus on the European perspective. The business models - 'diversification', 'primary food production', 'value differentiation', 'service provision' and 'innovative operations' - are classified by Liu (2015) by conducting a case study investigation of urban agriculture on the global scale. Recently, van der Schans has proposed an extended list of urban agriculture's business models: 'low cost', 'differentiation', 'diversification', 'the commons' and 'experience' (Van der Schans, 2015; Van der Schans et al., 2016). These classifications of urban agriculture's business models focus mostly on urban farming as the primary business-oriented activities under the wider UA umbrella. Research and development - especially in the

\begin{tabular}{|c|c|c|c|c|c|}
\hline $\begin{array}{l}\text { Van der Schans } \\
(2010)\end{array}$ & $\begin{array}{l}\text { Hedin } \\
(2015)\end{array}$ & $\underset{(2015)}{\operatorname{Liu}}$ & $\begin{array}{c}\text { Van der Schans } \\
(2015)\end{array}$ & $\begin{array}{c}\text { Pölling et al. } \\
(2015)\end{array}$ & $\begin{array}{c}\text { Van der Schans } \\
\text { et al.(2016) }\end{array}$ \\
\hline - Specialisation & - Small production & $\begin{array}{c}\text { - Primary food } \\
\text { production }\end{array}$ & - Low cost & - Cost reduction & - Low cost \\
\hline - Differentiation & - Large production & - Value differentiation & - Differentiation & - Differentiation & - Differentiation \\
\hline \multirow[t]{4}{*}{ - Diversification } & - Secondary purpose & - Diversification & - Diversification & - Diversification & - Diversification \\
\hline & & - Service provision & $\begin{array}{l}\text { - Reclaiming the } \\
\text { commons }\end{array}$ & - Shared economy & - The commons \\
\hline & & - Innovative operations & - Experience & - Experience & - Experience \\
\hline & & & & - Experimental & \\
\hline
\end{tabular}

Tab. 1: Classification of urban agriculture's business models

Source: authors' elaboration 
field of high-tech innovations, often in inner-city locations adds business cases to traditional city-adjustments of urban farming. Additionally, emerging non-profit-oriented initiatives (urban gardening) "may operate their garden as a collective rather than as an allotment and residential gardeners may be involved in commercial gardening" (McClintock, 2014, p. 150).

Recent studies proposing 'innovative operations', 'the commons' and 'experiences' demonstrate that the business model concept is under scientific discussion, rich in its expressions and innovations, and that it differs with regard to the research subject. This paper however focuses on the well-established business models of 'low-cost specialisation', 'differentiation', and 'diversification', while not ignoring the other concepts. Additionally, it analyses solely traditional farms adjusting to urban conditions with city-oriented strategies and business models, while (commercialising) urban gardening initiatives are beyond the scope of the paper.

The model of 'low-cost specialisation' is associated with high added-value crop production, a typical farm activity. Herein, products with high added values, high transportation costs, freshness and high perishability, are characteristic for urban areas as proximity to customers possesses comparative advantages (Gardner, 1994; Heimlich and Barnard, 1992; Lohrberg, 2001; Mougeot, 1999; Zasada et al., 2011). Urban encroachment and comparable small areas of farmland in and around cities necessitate higher added values per farmland unit to maintain or enhance economic viability. Agglomerations, in which high-value here greenhouse - production has been identified as an important farm activity, comprise, for example, Paris and Lisbon (Péron and Geoffriau, 2007), Copenhagen (Zasada et al., 2011), The Hague (Korthals Altes and Van Rij, 2013), Barcelona (Dupras et al., 2016) and Metropolis Ruhr in Germany (Pölling, 2016). Anonymous high value crop production for the mass market without appropriate upand down-stream management, however, is not sufficient anymore: contested global markets increasingly demand differentiation in production and/or marketing.

The business model of 'differentiation' embraces niche production as well as differentiation in processing and marketing by integrating (parts of) the added-value chain on-farm. Niches, like exotic species or traditional breeds, create unique selling propositions and business options for urban farms (Van Der Schans, 2010). City environments encourage farmers to identify activities along the whole added-value chain to innovate the business towards 'differentiation', with the aim of obtaining higher prices (Prain and de Zeeuw, 2007; Zasada, 2011). Vertical integration shortens the added-value chain and creates manifold additional business fields that can be used by differentiated urban farms (Van Der Schans, 2010). Within this business model, specific product features are very important to be successful, but personal producerconsumer relationships, transparency and authenticity help in terms of 'standing out from the crowd'. Cities offer favourable conditions for direct sale or other short supply chains (restaurants, canteens, other farm shops, etc.), eliminating additional intermediaries (Beauchesne and Bryant, 1999; Lohrberg, 2010; Zasada, 2011).
'Diversification' in production as well as into services, is another characteristic farm business model within urban areas. The variety of exploited commercial services connected to or close to agricultural production cover a wide range, such as agro-tourism (recreation, gastronomy), social support (education, therapy, health, caretaking), and further public and private services (maintenance, log work, winter road clearance) (Bailey et al., 2000; Beauchesne and Bryant, 1999; Busck et al., 2006; Heimlich and Barnard, 1992; Lohrberg and Timpe, 2011; Vogl et al., 2003; Zasada, 2011). Among others, horse services (Bailey et al., 2000; Elgåker and Wilton, 2008; Quetier and Gordon, 2003; Zasada et al., 2011), education services, and care farming (Siebert et al., 2009; Van der Schans, 2010; Wiskerke, 2009) are frequently used by farms located in rather densely populated areas due to the presence of a large number of (possible) clients.

Existing knowledge on UA is largely based on isolated investigations of farms or intra-regional groups of farms. Thus, this paper aims to add knowledge to the emerging research field of urban agriculture's business models by comparing selected urban farms from Spain, Italy and Germany. This allows for the detection of more generalisable features of UA's business models in Europe.

\section{Method and materials}

The method adopted was elaborated within the EU COSTAction "Urban Agriculture Europe" (2012-2016) Working Group on "Entrepreneurial models of urban agriculture"1. This group focused specifically on the business model concept and they developed and tested a standardised questionnaire addressing people from European UA, with a focus on urban farming. They also adopted the Business Model Canvas to characterise and describe the businesses models of urban farms and their underlying strategies.

\subsection{Data collection}

The farms under consideration in this study are chosen as suitable examples of urban farming's characteristic business models adjusted adequately to the urban environments. These choices are based on national and more regional expertise with existing networks in practical farming, and rooted in a diversified approach to analyse a wide range of business cases (see Fig. 1). Within this panorama, selected good practices of urban farming show key strategies in urban areas, how they exploit the consumer potentials of urban markets and evade the constraints originating from the urban environment. They are influenced by metropolitan dynamisms, including a strong competition for land and large consumer potentials in their vicinity. The investigated cases are not urban farms which can be generalised for the case study regions and nations, but they serve as best practices suitable to learn from for the wider audiences of farms influenced by cities. In-depth personal farm interviews were carried out to detect information on and insights into urban farms and their underlying strategies and business models. The questionnaire asked for several quantitative and qualitative data items, especially geographical setting, agricultural practice, marketing, institutional environment, success factors, obstacles, clients' expectations, policy options and societal benefits.

\footnotetext{
${ }^{1}$ WG 3 on "Entrepreneurial models of urban agriculture" had been coordinated by Wolf Lorleberg and Pedro Mendes Moreira and attended by 41 participants.
} 


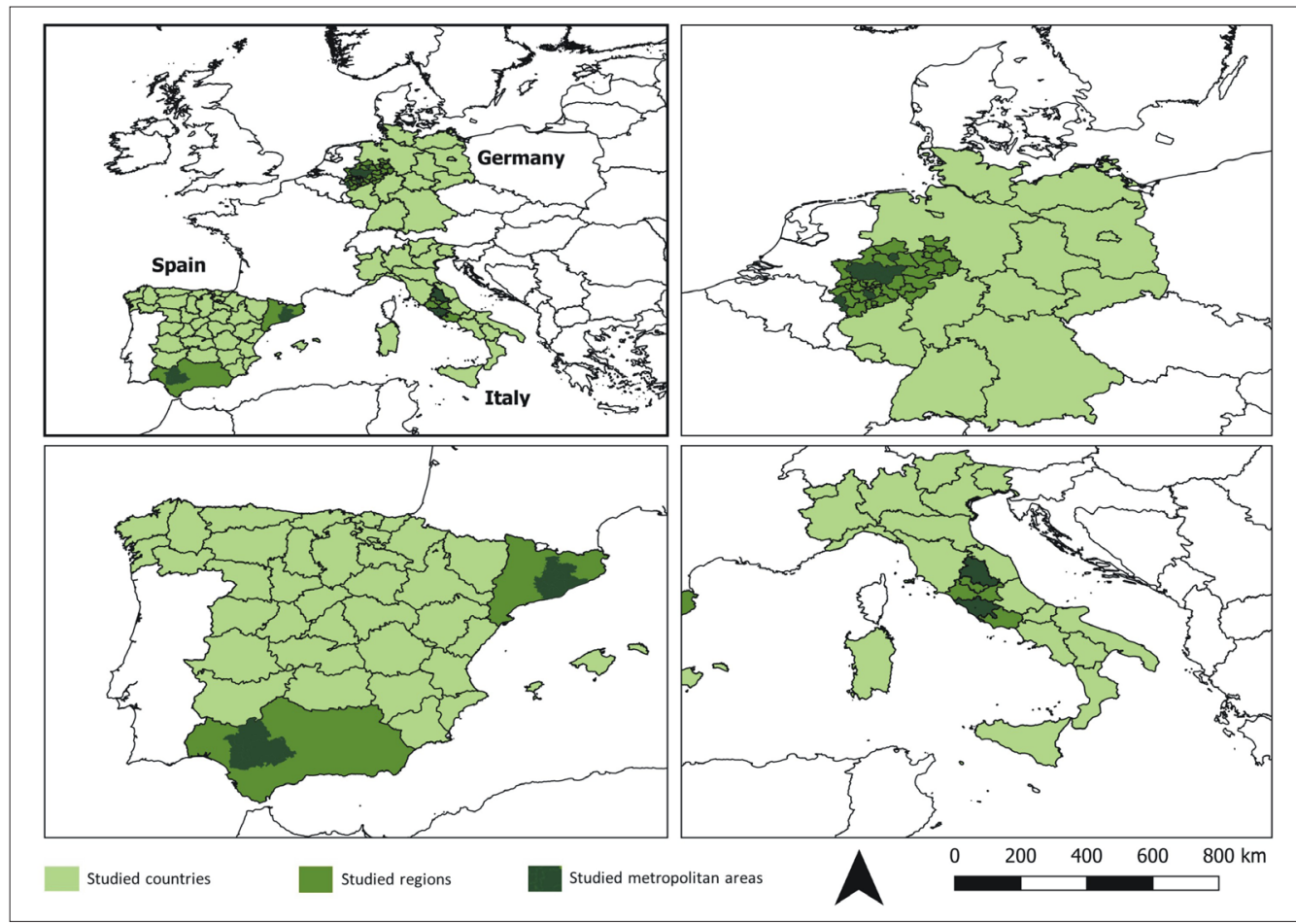

Fig. 1: Case study regions of urban farming in Spain, Italy, and Germany Source: authors' elaboration

\subsection{Analysis: The Business Model Canvas}

The strategic management template Business Model Canvas (BMC) is suitable in providing an overview of value creation and capture, relationships, success factors and comparisons of the companies - here urban farms. Osterwalder, Pigneur and more than 470 practitioners from 45 countries published "Business Model Generation", including the BMC (Osterwalder and Pigneur, 2010). In their definition, "a business model describes the rationale of how an organisation creates, delivers, and captures value" (Osterwalder and Pigneur, 2010, p. 14). The BMC is named simply and understandably, while not oversimplifying its entrepreneurial activities. It is a strategic management template to document not only those existing, but also to develop and visualise new business model ideas. The BMC's four main components are customers, offer, infrastructure and financial viability. BMC is a tool, which provides helpful overviews of companies to emphasise key success factors, to detect barriers, to compare competitors, and to generate business ideas and innovations: "Although the Canvas has a simple structure, it forms a complex system of interdependencies between the different elements" (Henriksen et al., 2012, p. 34). The four main components are the backbone of BMC's nine basic building blocks, which are briefly introduced in Table 2.

\begin{tabular}{|c|c|c|c|c|}
\hline $\begin{array}{c}8 . \\
\text { Key partnership }\end{array}$ & $\begin{array}{c}7 . \\
\text { Key activities }\end{array}$ & $\begin{array}{c}2 . \\
\text { Value proposition }\end{array}$ & $\begin{array}{c}4 . \\
\text { Customer relationship }\end{array}$ & $\begin{array}{c}1 . \\
\text { Customer segments }\end{array}$ \\
\hline \multirow[t]{2}{*}{$\begin{array}{l}\text { The network of suppliers } \\
\text { and partners that make } \\
\text { the business model } \\
\text { working }\end{array}$} & $\begin{array}{l}\text { The most important } \\
\text { activities a company } \\
\text { must do to make its } \\
\text { business model working }\end{array}$ & \multirow[t]{2}{*}{$\begin{array}{c}\text { The bundle of products } \\
\text { and services that create } \\
\text { value for a specific } \\
\text { customer segment }\end{array}$} & $\begin{array}{l}\text { The types of relationships } \\
\text { a company establishes } \\
\text { with specific customer } \\
\text { segments }\end{array}$ & \multirow[t]{2}{*}{$\begin{array}{l}\text { The different groups of } \\
\text { people and organisations } \\
\text { that the company aims } \\
\text { to reach and serve by its } \\
\text { products and services }\end{array}$} \\
\hline & $\begin{array}{c}\mathbf{6} . \\
\text { Key resources } \\
\text { The most important } \\
\text { assets required to make a } \\
\text { business model working }\end{array}$ & & $\begin{array}{c}\text { 3. } \\
\text { Channels } \\
\text { How a company } \\
\text { communicates with and } \\
\text { reaches its customer } \\
\text { segments to deliver value } \\
\text { proposition }\end{array}$ & \\
\hline \multicolumn{3}{|c|}{9.} & \multicolumn{2}{|l|}{5.} \\
\hline \multicolumn{2}{|r|}{ Cost structure } & \multicolumn{3}{|c|}{ Revenue streams } \\
\hline \multicolumn{2}{|r|}{$\begin{array}{l}\text { All costs incurred to } \\
\text { operate a business model }\end{array}$} & \multicolumn{3}{|c|}{$\begin{array}{l}\text { The cash a company } \\
\text { generates from each } \\
\text { customer segment }\end{array}$} \\
\hline
\end{tabular}

Tab. 2: The Business Model Canvas, with short indications of the nine basic building blocks Source: authors' conceptualisation based on Osterwalder and Pigneur (2010) 
The BMC is used in this inter-regional analysis to define urban farming's characteristic business models - low cost specialisation, differentiation and diversification - in the three study countries, Spain, Italy and Germany. Herein, diversification is subdivided into two strategies: one representing farms diversifying into services outside of agricultural production; and one for businesses diversifying into farming, e.g. health care or educational institutes. Each UA business model is presented by indicating specific findings for the nine basic building blocks of BMC. The nine blocks refer to different aspects orienting the analysis, both on social and economic findings.

We note that the quantitative data collected by interviewers are fragmented and differ severely between countries and regions. This has to be seen in the light of very sensitive economic data, which are partly offered by the interviewed farms due to long-established contacts with the interviewers' institutes and trust between them, but partly also not. So the data (both quantitative and qualitative) collected have been mobilised to compare, describe and characterise the business models. Although based largely on qualitative and more general findings, this approach allows comparisons of business models and also the detection of inter-regional similarities and differences in adjusting to cities.

Scholars investigating sustainable innovation have largely neglected "the way in which firms need to combine a value proposition, the organisation of the upstream and downstream value chain and a financial model in order to bring sustainable innovation to the market" (Boons and LüdekeFreund, 2013, p. 9). Thus, this paper addresses this gap. We note, however, that BMC has already been used to analyse UA in studies such as: a sophisticated collection of urban and peri-urban agriculture examples in the Netherlands (Nationale Federatie Stadsgerichte Landbouw, 2013); the analysis of an organic farm situated in Vietnamese Ho Chi Minh City (Nguyen and Truong, 2013); an investigation of agri-/horticultural enterprises, producer organisations, and cooperatives in Latin America (Lundy, 2012); and an overview of urban gardening initiatives and projects in San Francisco (Ganguly et al., 2011). Before presenting the results, it has to be emphasised that the business models briefly introduced in the theoretical background support the analysis and are suitable to classify urban farms. Yet, many farms do not fit fully and solely into one of the business models, but rather belong dominantly to one of UA's business models and make use of elements of other business models simultaneously as well. Thus, many farms can be characterised by highlighting one business model, but the exploitation of additional strategies from other business models is present in many cases and has to be considered.

\section{Results}

This paper analyses 50 urban farms located in Spain, Italy, and Germany (see Fig. 1, Tab. 3). Thirteen of the farms are located in two Spanish metropolitan areas: Seville Metropolitan Area (SMA) and Barcelona Metropolitan Region (BMR). The agricultural context dominates in SMA, where three farms are situated, while there is a stronger domination of urban land uses in BMR for the remaining ten Spanish cases. The farm sizes of the case studies in BMR and SMA are smaller than the average sizes of farms in their regions. Other determinants such as the high density of population, urban sprawl and infrastructure density, and the general scarcity of farmland due to natural factors (hilly areas, water availability and proximity to the sea), are responsible for the comparably small land resources of the farms. The average job intensity in BMR is higher than the average for its wider region, but it is lower in SMA, which can be explained by agribusiness specialisations, large farm plots, the cultivation of cash crops, and the activities conducted by the urban farmers.

The 16 Italian urban farms in this study are also located in two urban areas: the metropolitan areas of Rome and Perugia, $150 \mathrm{~km}$ north of Rome. These areas differ by size and a different density of green areas. With reference to the green areas, $32 \%$ of the large metropolitan area of Rome is farmland, about $30 \%$ are protected areas, and the

\begin{tabular}{lcccc}
\hline \multicolumn{1}{c}{ Business model (Country) } & Number of farms & $\begin{array}{c}\text { Average farm size } \\
\text { [ha] }\end{array}$ & $\begin{array}{c}\text { Average number } \\
\text { of jobs } \\
\text { [full-time equivalent] }\end{array}$ & $\begin{array}{c}\text { Average job intensity } \\
\text { [number of jobs/ha] }\end{array}$ \\
\hline Low-cost specialised farms (SP) & 3 & 40.12 & 1.28 & 0.14 \\
Low cost specialised farms (IT) & 3 & 22.17 & 8.67 & 0.39 \\
Low-cost specialised farms (GE) & 2 & 20.00 & 9.00 & 0.45 \\
Differentiated farms (SP) & 1 & 2.00 & 4.00 & 2.00 \\
Differentiated farms (IT) & 2 & 102.50 & 9.50 & 0.09 \\
Differentiated farms (GE) & 8 & 75.50 & 7.90 & 0.10 \\
Diversified farms (SP) & 9 & 22.11 & 4.25 & 0.19 \\
Diversified farms (IT) & 6 & 16.00 & 5.67 & 0.35 \\
Diversified farms (GE) & 4 & 122.50 & 13.10 & 0.10 \\
Diversifiers into agriculture (SP) & - & - & - & - \\
Diversifiers into agriculture (IT) & 5 & 10.30 & 4.00 & 0.39 \\
Diversifiers into agriculture (GE) & 7 & 18.20 & 43.20 & 2.73 \\
Sum/Average (SP) & 13 & 21.41 & 3.17 & 0.77 \\
Sum/Average (IT) & 16 & 26.94 & 6.19 & 0.23 \\
Sum/Average (GE) & 21 & 60.10 & 20.80 & 0.35 \\
\hline
\end{tabular}

Tab. 3: Key characteristics of the surveyed urban farms in Spain, Italy and Germany Source: authors' elaboration 
urban green-area density reaches about $3 \%$. The city of Perugia, on the other hand, has a land area equal to onethird and a population equal to $1 / 17$ of that of the Rome metropolitan area, and is characterised by an even higher share of farmland (44\%), a lower density of protected areas (16\%), and by the same share of urban green-areas (ca. $3 \%$ ). The average size of the surveyed farms is higher than the national average ( $8.45 \mathrm{ha}$ ). This shows that a city's proximity does not necessarily imply a reduced agricultural area available for production of goods and services. The average labour intensity is 0.23 man-work units per hectare and is, most likely, higher than the national average, which refers to the total number of employees and, therefore, it also includes a number of part-time workers ( 0.29 agricultural employees per hectare). These structural data underline the vitality of the urban farms subject to study, which are busy in providing high value-added goods and services that require high use of productive resources. All of the surveyed farms have two common features: (i) production according to organic farming methods; and (ii) operating the direct sale of agricultural products through farm shops, farmers' markets, and collective purchase of goods (Italian: Gruppi di Acquisto Solidale, GAS).

The 21 urban farms interviewed in Germany's federal state of North Rhine-Westphalia represent good-practices of the characteristic business models of urbanised regions, which are located in Metropolis Ruhr, Cologne, Aachen and Münster. These farms' key characteristics considered herein are summarised in Table 2 (also Pölling, 2016). The average farm size of urban farming's good practices cases is similar to the German average, but differences between the business models are significant.

The geographical context of the case studies covers a wide spectrum of urban areas in European regions. Urban agriculture is often associated with high-density urban areas such as Rome, Cologne and Barcelona. In these situations, farming is pushed outwards due to centrifugal forces of population growth and urban encroachment. The 15 case studies in the Ruhr Metropolis address urban farming in an old highly-industrialised metropolitan region. Here, urban farms act in a polycentric net of cities historically dominated by heavy industries. Green corridors between these areas, covering a considerable amount of land, are predominantly used for farming. Urban farming in the peri-urban areas of Spain and Italy reinforces the economic dimension of urban agriculture at the sub-regional scale to achieve better relationships between farmers and urban population. In these peri-urban areas where original rings of forests were considerably replaced by farming activities, urban farming is currently providing an important range of economic, cultural and environmental functions.

We find three business models known from the literature (low-cost specialisation, differentiation and diversification) that unfold in four groups due to the splitting of diversification into two subgroups: agricultural diversification and diversification into agriculture. Each of these four groups is presented in subsequent sections and synthesised afterwards.

\subsection{Low-cost specialisation}

The farm activities categorised under low-cost specialisation differ largely according the case location chosen. The Spanish low-cost specialised farms differ from the Italian and German ones, which are quite similar (see Tab. 4) in that such farms have very standardised activities and aim to offer just one or very few products and services, concentrating on bringing down the costs. The city's proximity enables them to cover specific needs like the demand for fresh vegetables and ornamental plants, or to practise leisure horse-riding without being forced to move very far away from town. As an example of the German and the Italian cases, farms located in the city of Rome have comparably large agricultural areas pursuing scale economies. Thus, the business models of the Italian and Germany low-cost specialised farms described via BMC's nine basic building blocks show many overlaps - largely the same customer segments, value propositions, channels, customer relationships, etc.

While the Italian and German case studies specialise in certain values (direct sale or high quality product, e.g. organic produce) and customer segments (people requesting high-quality products or leisure activities), the three Spanish low-cost specialised farms, which are exclusively located in the Metropolitan Area of Seville, maximise margins via economies of scale and reduced cost structures. These low-cost urban farms need to develop survival strategies with agricultural activities to stay competitive in agricultural markets and compete for land with non-agricultural land users. These actions include exploitation of natural resources (irrigation, solar energy and land reclamation), agribusiness strategies and public support. The agribusiness strategies include adapting the land cover to local conditions; cooperatives and agroenterprises; hiring the labour force required to run and monitor highly engineered activities. The most important customer segments of these low-cost farms near Seville are export-oriented agro-food industries belonging to long value chains. On the contrary, the German and Italian specialised farms emphasise local customer demands.

The location of the Seville MA's low-cost urban farms matters: they are all located on a floodplain on which an historical network of urban centres has been developed. Based on the ancient colonisation, water areas and agricultural plots build the main natural resources for the urban population. Urban farming from the low-cost specialised farms is divorced from the leisure activities of the urban population. This is seen partly in the business choices towards large-scale production and partly because the spatial planning authorities do not consider these private farms as open spaces worthy of note. The situation could be turned around by applying green services and short supply chains valuable for citizens and city environments, and with potential private and public economic contributions. To obtain a better recognition, new ways of landscape-related management, for example support by urban planners, could be worthwhile.

\subsection{Differentiation}

The business model of 'differentiation' highlights, in the majority of cases, short supply food chains: mainly direct sale arrangements; short chains with only one or very few intermediaries (canteens, restaurants, etc.); and new forms of customer participation and co-production, such as the renta-field concept. Each of this sample's eleven differentiated farms uses at least one non-mainstream marketing strategy in agricultural production, processing or marketing. While only one urban farm is considered under the business model of differentiation in Spain, there are two in Italy and eight in Germany (see Tab. 5). The most frequent activity in this group is the vertical integration of the value-added chain by 


\begin{tabular}{|c|c|c|c|}
\hline & Spain & Italy & Germany \\
\hline \multirow[t]{3}{*}{ Customer segments } & - Agro-food industries & $\begin{array}{l}\text { - People from the area requesting } \\
\text { fresh vegetables and ornamental } \\
\text { plants }\end{array}$ & $\begin{array}{l}\text { - People requesting high-quality } \\
\text { products }\end{array}$ \\
\hline & - Export-orientation & $\begin{array}{l}\text { - People requesting leisure } \\
\text { activities/enjoyment }\end{array}$ & $\begin{array}{l}\text { - People from the area requesting } \\
\text { leisure activities/enjoyment }\end{array}$ \\
\hline & - Farmers Associations & $\begin{array}{l}\text { - Families willing to cultivate } \\
\text { a vegetable garden }\end{array}$ & \\
\hline \multirow[t]{5}{*}{ Value proposition } & - Citrus and rice varieties & $\begin{array}{l}\text { - Fresh vegetables and } \\
\text { ornamental plants }\end{array}$ & - High-quality products \\
\hline & $\begin{array}{l}\text { - Low cost: economies of scale, } \\
\text { partly also direct marketing }\end{array}$ & - Courses/Education & - Specialties (niches) \\
\hline & & - Specialties (niches) & - Courses/Education \\
\hline & & - Accessibility of green areas & \\
\hline & & - Rent-a-field & \\
\hline \multirow[t]{3}{*}{ Channels } & - Agro-food industries & - On-farm & - On-farm \\
\hline & - Agribusiness & & \\
\hline & - On-farm & & \\
\hline \multirow[t]{2}{*}{ Customer relationships } & $\begin{array}{l}\text { - Personal to agro-food industries } \\
\text { and exporters }\end{array}$ & - Personal assistance & - Personal; Individual \\
\hline & - Dedicated personal assistance & & \\
\hline \multirow[t]{3}{*}{ Revenue streams } & - Long supply chains & - Product sales & - Product sales \\
\hline & - Short supply chains & $\begin{array}{l}\text { - High turnover per farmland } \\
\text { unit }\end{array}$ & $\begin{array}{l}\text { - High turnover per farmland } \\
\text { unit }\end{array}$ \\
\hline & - Quantity & - Fees for services & - Fees for services \\
\hline \multirow[t]{4}{*}{ Key resources } & - Fertility of soils & - Business attitude & - Knowledge \\
\hline & - Irrigation infrastructure & - Land & - Labour \\
\hline & - Citrus and rice varieties & - Labour & - Land \\
\hline & - Farm location & - Machinery/ Equipment & - Machinery/ Equipment \\
\hline \multirow[t]{3}{*}{ Key activities } & $\begin{array}{l}\text { - Production and long supply } \\
\text { chain marketing }\end{array}$ & $\begin{array}{l}\text { - Standardised activities: fresh } \\
\text { vegetables/ornamental plants }\end{array}$ & $\begin{array}{l}\text { - Production and services } \\
\text { (floriculture, horse keeping/services) }\end{array}$ \\
\hline & - Direct sale & $\begin{array}{l}\text { - Production and services } \\
\text { (floriculture, horse keeping/services) }\end{array}$ & \\
\hline & & $\begin{array}{l}\text { - Rent-a-field (preparation/ } \\
\text { consultation) }\end{array}$ & \\
\hline \multirow[t]{3}{*}{ Key partnerships } & - Agro-food industries & - Thematic Networks & - Associations \\
\hline & - Farmers' Associations & - Associations & - Thematic Networks \\
\hline & & & - Neighbouring farms \\
\hline \multirow[t]{5}{*}{ Cost structure } & - Water and electricity & - Wages & - Wages \\
\hline & - Wages & - Running costs & - Running costs \\
\hline & - Equipment and machinery hiring & - Equipment & - Equipment \\
\hline & - CAP requirements & - Training & - Training \\
\hline & $\begin{array}{l}\text { - Cost reduction via economies } \\
\text { of scale }\end{array}$ & - Cost reduction via specialisation & - Cost reduction via specialisation \\
\hline \multirow[t]{3}{*}{ Key conclusion } & - Agribusiness & $\begin{array}{l}\text { - Focusing solely on one/very few } \\
\text { products; often this product used } \\
\text { to broaden income sources }\end{array}$ & $\begin{array}{l}\text { - Focusing solely on one product; } \\
\text { often this product used to } \\
\text { broaden income sources }\end{array}$ \\
\hline & - Long to short value chains & & \\
\hline & $\begin{array}{l}\text { - Good accessibility in a nice } \\
\text { atmosphere }\end{array}$ & & \\
\hline
\end{tabular}

Tab. 4: Summary overview of the low-cost specialised urban farms: Key notes of the nine basic building blocks for each of the three case study countries Source: authors' elaboration 


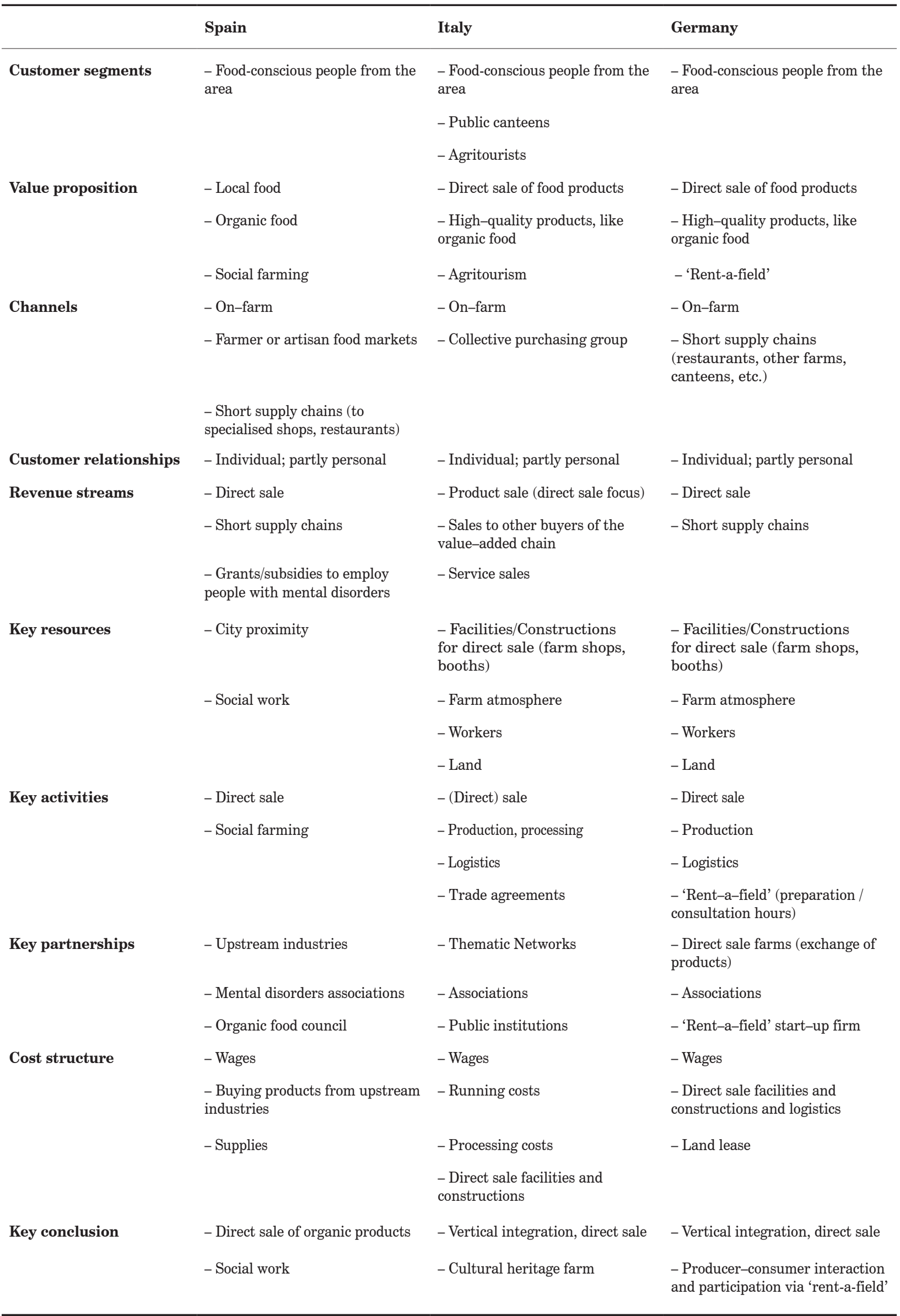

Tab. 5: Summary overview of the differentiated urban farms: Key notes of the nine basic building blocks for each of the three case study countries

Source: authors' elaboration 
marketing products directly to the consumers or via short supply chains eliminating intermediaries, while one German differentiated farm also makes use of the participatory 'rent-a-field'-concept. The direct sale of products represents the core business of differentiated farms. This vertical integration achieved by the farms provides the real strength that guarantees consumers maximum safety with respect to the origin of the products, as well as its contribution to the local economy. By doing so, the differentiated farms step out from the anonymous mass market of agrarian products and establish direct producer-consumer relationships built on trust. The farm atmosphere, the farmers' and their families' attitudes and the surrounding ambience, are relevant soft factors for the successful differentiation of farm strategies. High-value (vegetables, fruits, berries, flowers, etc.) and high-quality production (organic labelling) support the implementation of short supply chains.

With the 'rent-a-field' concept, the farmer rents small parcels - mainly of pre-sown vegetables - to interested city dwellers for one season. The renters are responsible for the further cultivation and harvest work, but the farmers offer exchange of knowledge, tools and water.

The Spanish differentiated farm is a small chicken farm producing organic eggs. The main channels used to sell its production are on-farm, farmers' markets, and short supply chains to specialised shops and restaurants without intermediaries. The main revenues originate from egg sales, grants and subsidies, where the latter are linked to their care taking of people with special needs. This farm employs as a side issue people with risk of social exclusion for their mental disorders. It has been established for selffulfilling job opportunities for citizens with handicaps or other special needs.

The two Italian differentiated farms also integrate some elements of diversification into their business portfolio; however, the short supply chain focus prevails as most important for their businesses. Apart from direct sale arrangements, the farm in Perugia runs agritourism activities that involve a number of cultural and recreational events, while the one in Rome performs social activities through work inclusion of people at the margins of society (e.g. in-mates and immigrants). In both cases, revenues from the agricultural activities have allowed the companies to maintain and enhance their cultural and historical buildings, thus fulfilling also the functions of promotion of culture and local heritage.

\subsection{Diversification}

\subsubsection{Agricultural diversification}

Most of the surveyed diversified farms apply service provisions linked somehow to agricultural production (Tab. 5). Apart from recreational aspects, social and cultural issues play another major role, including education, therapy and environmental consciousness. For example, educational aspects are demonstrated in the Italian agricultural panorama as different kindergarten farms are emerging, established in peri-urban areas with the aim both to offer an alternative to traditional educational provision and to stimulate a process of cultural re-assessment to help the farming sector recover the social function it has served for centuries (Torquati et al., 2015). The most important services among the Italian diversified farms are farmers who receive school groups and families requesting learning and leisure time at agricultural facilities and in green spaces. Additionally, some farms add social inclusion aspects of disadvantaged people into their businesses. Here, caretaking is used as a diversification, while the diversifiers into agriculture (see below) are coming from outside farming into this sector to use farming as a vehicle for social work and therapies.

Services are offered to a wide range of customer segments in the German case study farms, especially via agritourism services like gastronomy, accommodation and horses. Three of the four diversified farms developed special diversification strategies: one by integrating 'land art', one by offering 'swingolf', and one by integrating do-it-yourself leisure-time gardening via 'rent-a-field'. The use of certain cultivation measures on farmland, like flower strips, ploughing patterns, etc., results in so-called 'land art', which attracts many people from the nearby settlement areas. 'Swingolf' is an easy kind of golf open for all people regardless of their golf skills. Apart from service diversification, German farms are on average also characterised by the largest farmland capital, which allows product diversification in crop production and livestock breeding. This widens the product range. Generally, the diversified farms broaden their revenue streams, which reduce dependence on one specific income thread, but in parallel creates complexity in everyday work and management, including the costs. While the provided services connected with farming build the core business for these farms, agricultural production is a minor business path. The focus on services is partly also connected with direct sale arrangements (differentiation) to exploit several income sources.

Similar to the Italian and German diversified farms, the Spanish cases apply a huge variety of diversification measures, closely but also loosely linked to production. They offer on average more jobs than farms focusing on primary production (Tab. 3). The most common services offered by the Spanish diversified farms are education (children), cultural (local heritage), gastronomy, and event (concerts, readings, sport) services. It can be recognised, however, that due to the location of the Spanish cases in an agricultural area characterised by viticulture, wine issues play a considerable role, parallel to and in co-existence with diversification measures (Tab. 6). For services like cultural heritage and gastronomy, wine production can be smoothly connected to create profitable synergies. These are good examples in showing how local production can be interwoven with diversification activities linked to agricultural production, in this case to wine.

\subsubsection{Diversification into agriculture}

This study puts a special focus on diversification into agriculture, defined here as public and private institutions offering care-taking for disadvantaged people or for other means (cultural heritage, landscape management). They have in common that non-farmers start farming activities. While no Spanish case study is considered here, five Italian and seven German care farms are analysed as diversifiers into agriculture (see Tab. 7). All cases are related to the specific needs of citizens who have found a common bond in agriculture to address and resolve issues related to the social sphere in the broadest sense.

These organisations include the Capanne prison social farm in Perugia, designed to make it possible for inmates to be able to learn a trade that will facilitate their social integration once their sentence time is served and that, simultaneously, makes them feel useful during their time in prison, also regaining some dignity linked to an honest 


\begin{tabular}{|c|c|c|c|}
\hline & Spain & Italy & Germany \\
\hline \multirow[t]{4}{*}{ Customer segments } & $\begin{array}{l}\text { - Families/groups of people interested } \\
\text { in farm activities linked to wine }\end{array}$ & $\begin{array}{l}\text { Broadly addressing customer } \\
\text { segments from the area }\end{array}$ & $\begin{array}{l}\text { - Broadly addressing customer } \\
\text { segments from the area }\end{array}$ \\
\hline & - Wine tourists & - Families & - Families \\
\hline & & - Children & - Children \\
\hline & & - People with special needs & \\
\hline \multirow[t]{5}{*}{ Value proposition } & $\begin{array}{l}\text { Services: education, culture, } \\
\text { gastronomy, events }\end{array}$ & - Agritourism Work & $\begin{array}{l}\text { - Services: education, culture, } \\
\text { gastronomy, events, sports }\end{array}$ \\
\hline & - Local and regional food & - Courses/Education & - Broad production basis \\
\hline & - Organic food & - Direct sale of food & \\
\hline & $\begin{array}{l}\text { - Wines and "cavas" (sparkling wines) } \\
\text { from a protected designation of origin }\end{array}$ & - Organic products & \\
\hline & - Local varieties of wine & - Assistance & \\
\hline \multirow[t]{2}{*}{ Channels } & - On-farm & - On-farm & - On-farm \\
\hline & $\begin{array}{l}\text { - Farmer or artisan food markets, } \\
\text { - Short supply chains }\end{array}$ & - Collective purchasing group & \\
\hline \multirow[t]{2}{*}{ Customer relationships } & $\begin{array}{l}\text { - Off-farm activities individual; } \\
\text { partly personal }\end{array}$ & - Personal; partly individual & - Personal; partly individual \\
\hline & & - Community & \\
\hline \multirow[t]{3}{*}{ Revenue streams } & $\begin{array}{l}\text { - Fees for services, like educational, } \\
\text { leisure and cultural activities/events }\end{array}$ & $\begin{array}{l}\text { - Fees for services, like educational, } \\
\text { leisure and cultural activities/events }\end{array}$ & $\begin{array}{l}\text { - Fees for services, like educational, } \\
\text { leisure and cultural activities/events }\end{array}$ \\
\hline & - Direct sales/Short supply chains & - Product sales & - From production \\
\hline & - Long supply chains & & \\
\hline \multirow[t]{5}{*}{ Key resources } & - Landscape & - Farm atmosphere and surrounding & - Farm atmosphere and surrounding \\
\hline & - City proximity & - Farmland & - Farmland \\
\hline & - Heritage & - Workers & - Open-mindedness \\
\hline & & - Open-mindedness & - Workers \\
\hline & & - Network with public institutions & \\
\hline \multirow[t]{6}{*}{ Key activities } & - Educational activities & - Educational activities & - Educational activities \\
\hline & - Leisure activities & - Leisure activities (agritourism) & $\begin{array}{l}\text { - Leisure activities } \\
\text { ('Swingolf'/'rent-a-field') }\end{array}$ \\
\hline & - Cultural events & - Therapies, assistance, formation & - Cultural events ('Land art') \\
\hline & - Gastronomy & $\begin{array}{l}\text { - Production, partly including the } \\
\text { value-added chain }\end{array}$ & - Gastronomy \\
\hline & - Events & & - Events \\
\hline & $\begin{array}{l}\text { - Production and direct sale; } \\
\text { partly long chains }\end{array}$ & & $\begin{array}{l}\text { - Production, partly including the } \\
\text { value-added chain }\end{array}$ \\
\hline \multirow[t]{6}{*}{ Key partnerships } & - Local restaurants or local chefs & - Thematic working groups & - Thematic working groups \\
\hline & - Local farmers & - Associations & - Associations \\
\hline & $\begin{array}{l}\text { - Protected designation of origin } \\
\text { council }\end{array}$ & - Public institutions & \\
\hline & - Artists for cultural events & - Cultural forums & \\
\hline & - Upstream industries & & \\
\hline & - Organic food council & & \\
\hline \multirow[t]{5}{*}{ Cost structure } & - Running the services & - Running the services & - Running the services \\
\hline & - Wages & - Wages & - Wages \\
\hline & - Advertising and marketing & - Constructions for offering services & - Land lease \\
\hline & - Upstream material providers & - Various inputs (resources) required & - Various inputs (resources) required \\
\hline & - Land lease & & \\
\hline \multirow[t]{2}{*}{ Key conclusion } & $\begin{array}{l}\text { - Non-agricultural service activities } \\
\text { (also to promote products) }\end{array}$ & $\begin{array}{l}\text { - Broadening approach into } \\
\text { services connected to farming }\end{array}$ & $\begin{array}{l}\text { - Broadening approach into } \\
\text { services connected to farming }\end{array}$ \\
\hline & - Direct sale & & - Production diversification \\
\hline
\end{tabular}

Tab. 6: Summary overview of the diversified urban farms: Key notes of the nine basic building blocks for each of the three case study countries. Source: authors' elaboration 


\begin{tabular}{|c|c|c|}
\hline & Italy & Germany \\
\hline \multirow[t]{4}{*}{ Customer segments } & - Clients with special needs & - Clients with special needs \\
\hline & - Mentally and physically disabled people & - Mentally and physically disabled people \\
\hline & - People with social disadvantages & - People with social disadvantages \\
\hline & - People interested in cultural tourism & - People interested in cultural tourism \\
\hline \multirow[t]{7}{*}{ Value proposition } & $\begin{array}{l}\text { - Work inclusion: Places to work in farming, } \\
\text { including processing, marketing, services }\end{array}$ & $\begin{array}{l}\text { - Work inclusion: Places to work in farming, } \\
\text { including processing, marketing, services }\end{array}$ \\
\hline & - Partly places to live & - Partly places to live \\
\hline & - Creating self-esteem & - Creating self-esteem \\
\hline & - Direct sale of organic products & - Direct sale of organic products \\
\hline & - Agritourism & - Agritourism \\
\hline & - Accessibility of green areas & \\
\hline & - Knowledge of local identity and heritage & \\
\hline \multirow[t]{3}{*}{ Channels } & - On-farm & - On-farm \\
\hline & - Collective purchasing group & \\
\hline & - Theme events & \\
\hline \multirow[t]{2}{*}{ Customer relationships } & $\begin{array}{l}\text { - Most often individual (with clients), partly } \\
\text { personal }\end{array}$ & $\begin{array}{l}\text { - Most often individual (with clients), partly } \\
\text { personal }\end{array}$ \\
\hline & - Community/Cooperative creation & \\
\hline \multirow[t]{3}{*}{ Revenue streams } & - Public payments for social work & - Public payments for social work \\
\hline & - Product sale & - Product sale \\
\hline & - Service fees, e. g. guided tours & \\
\hline \multirow[t]{4}{*}{ Key resources } & - Clients & - Clients \\
\hline & - Social workers & - Social workers \\
\hline & - Grant of property and land use & - Property \\
\hline & - Network with public institutions & - Network with public institutions \\
\hline \multirow[t]{6}{*}{ Key activities } & $\begin{array}{l}\text { - Rehabilitation of disabled or socially impaired } \\
\text { people via farming activities }\end{array}$ & $\begin{array}{l}\text { - Rehabilitation of disabled or socially impaired } \\
\text { people via farming activities }\end{array}$ \\
\hline & - Job creation & - Job creation \\
\hline & - Problem solving & - Problem solving \\
\hline & - Social assistance & - Social assistance \\
\hline & - Research for alternative sales channels & \\
\hline & - Enhancement of identity places & \\
\hline \multirow[t]{5}{*}{ Key partnerships } & - Social organisations & - Social organisations \\
\hline & $\begin{array}{l}\text { - Public institutions, job agencies, social welfare } \\
\text { offices }\end{array}$ & $\begin{array}{l}\text { - Public institutions, job agencies, social welfare } \\
\text { offices }\end{array}$ \\
\hline & - Associations & - Associations \\
\hline & - Research centres, University & \\
\hline & - Neighbouring farms & \\
\hline \multirow[t]{4}{*}{ Cost structure } & - Wages (social workers) & - Wages (social workers) \\
\hline & - Time-intensive assistance & - Time-intensive assistance \\
\hline & - Running costs & - Running costs \\
\hline & - Property/land lease & - Property/land lease \\
\hline \multirow[t]{2}{*}{ Key conclusion } & - Care farming for clients with special needs & - Care farming for clients with special needs \\
\hline & - Cultural heritage farm & \\
\hline
\end{tabular}

Tab. 7: Summary overview of the diversifiers into agriculture: Key notes of the nine basic building blocks for each of the three case study countries Source: authors' elaboration 
job. Other Italian social farms are built around existing daycare centres for young people with autism, which are real laboratories of ideas that start right from the agricultural production; or they connect with care centres for young immigrants, where church institutions have made available previously abandoned agricultural land to create community gardens linked to a joint purchasing group for the products. All of the seven German surveyed diversifiers into agriculture are social farms, which offer working (and living) places for people with special needs, like physically and mentally handicapped people as well as young adults facing problems on the regular labour market.

Although farm-specific characteristics and the processes of care farms differ between the individual farms to some extent, the general farm strategy is comparable. All care farms offer working places and partly also living places for clients with special needs. These clients are mentally or physically disabled, children with severe problems in family and/or school, and young adults facing problems entering the regular labour market. The farmland resources are rather small compared to many other farms (see Tab. 2), but the prevalence of organic farming and the maximisation of cultivated crops and kept animals enlarges the working opportunities for the clients. Farm production aims to create manifold tasks in the whole chain from production to processing and marketing, as well as in additional services offered to other customers of the farm, especially gastronomy. This diversified farm concept allows clients to conduct work which suits their special needs. The important success factors of care farms are qualified social workers and close connections to social entities, like job agencies, social welfare institutions, and also private social associations or companies.

One particular case, finally, is the farm established within a facility run by the Italian National Trust (FAI), the Forest of Saint Francis, which contributes, through the production of agricultural products and the preservation of a unique landscape, in connecting visitors to the local and Italian environment, culture and landscape heritage.

\subsection{Synthesis and discussion}

Many examples demonstrate the diversity of the business strategies run by farms, so that in many cases a dominant business model can be detected but often being added to by activities from other business models. Commonalities can be detected, however, between business models and between countries when synthesising the 50 urban farms in Spain, Italy, and Germany.

Regardless, we do have to admit that the number of lowcost specialised farms is limited in this survey and a stronger focus is put on diversification and differentiation business models of urban farming.

Our research fits also to the findings of Aubry and Kebir (2013) that a mass market orientation to bring down costs is no longer sufficient for agricultural activities when acting under urban environments with associated societal demands. An orientation to contested global markets alone causes fragility, and provides some reasons for the reduction of high value crop production in the Ruhr Metropolis, Germany, for example (Pölling et al., 2016).

Most of the surveyed farms focus in particular on local customer segments and via short supply chains of agricultural products and services. This is the case regardless of the country and regardless of the business model, except for the three low-cost farms situated near Seville (Spain). Rather, they focus very much on exportoriented agro-food industries by making use of their fertile soils and appropriate irrigation systems, which allow for the reduction of costs via economies of scale. On the contrary, the Italian and German farms belonging to the business model of low-cost specialisation focus on specialisation rather than low-cost; they specialise cost-efficiency on specific goods and services demanded by local populations.

Naturally, customer segments and value propositions differ between the four business model groups, while the majority of applied channels (on-farm) and customer relationships (personal, individual) are rather similar. This is a key difference to other non-city-adjusted farms and their underlying business models: the other farms' channels are predominantly off-farm and customer relationships are often non-personal due to their integration into long-value chains. All four business model categories are dominated by personal relationships, which is a particular strength of the surveyed farms. The channels and revenue streams - especially of diversification and differentiation groups - are similar, mainly because their agricultural activities are supported by short supply chains, often with direct sales, while lowcost specialised farms have a different market access via agribusiness relations.

The remaining building blocks of the BMC differ between the four groups according to the farm concept, the customer segments and value propositions. Groups of customers that companies reach and serve belong to different segments, each of which expresses a demand for partly non-traditional goods and services. The diversified farms cover a rather broad customer segment of people requesting some enjoyment or demanding other services linked to agriculture, while those segments are more clearly specified for the other three business models: clients with special needs (diversifiers into agriculture); food-conscious people (differentiated farms); and people requesting specific services, such as floristry courses and high-quality equestrian education in their leisure-time (specialised farms). These key customer segments are directly linked to the farms' value propositions. The value propositions to customers are: in terms of the business model of low-cost specialisation, comparable cheap products in the case of the Spanish low-cost urban farms in the Seville region, as well as specialised goods and goods; in the case of the differentiated farms, high-quality agricultural products offered via short, transparent and personal supply chains; and in the case of the two diversification business models, social, educational, cultural and recreational services.

Access to workers and farmland are key resources for all four business models; however, specific business models demand more land than others. The low-cost approach of farms around Seville demand comparably large properties to exploit cost-reduction benefits. Additionally, Italian differentiated and German diversified farms are comparably large (see Tab. 2). The German diversified farms cultivate a huge variety of crops and keep different livestock, both of which demand certain land resources. Additionally, activities such as horse-keeping and associated services, need farmland to produce fodder and offer pastures for the horses, and outdoor activities for the customers of equestrian services. The Italian primarily differentiated farms are comparably large due to their additional offers linked to diversification, which fits again with the above-mentioned reasons for the size of diversified farms in Germany. In the last decade, 
Italy's urban farming has changed considerably, with an orientation towards diversification and multifunctionality according to urban demands, and to the morphological, structural, historical and cultural features of the cities in which they developed. The Barcelona diversified farms are based on the monoculture of vines, and they include the three stages of agricultural entrepreneurship (production, agroindustry processing and sales and marketing). Offering a large number of activities related to agriculture, gastronomy and heritage is one way to promote their wines.

All business models emphasise the importance of location, meaning that green areas close to large customer segments within cities and agglomerations provide favourable framework conditions for personalised business. This is important both for the production of food and non-food agrarian products, and also for the provision of various services linked more or less loosely to agricultural production. Here the link between agricultural production (viticulture) and the provision of services as conducted in the Barcelona region shows suitable links to provide valuable synergies among them. Diversified farms in particular are bound to the beauty of their landscapes, cultural heritage and multifunctionality, which attracts customers from their cities.

More generally, this study shows that a huge variety of business cases exists within urban and peri-urban settings throughout Europe. Depending on the local markets, the agricultural history of the region and to more recent cityadjustments conducted by the urban farmers, characteristic business models can be identified with their partly similar, but also partly different features.

\section{Conclusions}

The analysis conducted in selected metropolitan areas of Spain, Italy, and Germany demonstrates that urban farming adjusts to specific urban conditions in manifold ways. Inter-regional similarities become obvious when comparing the business model paths of lowcost specialisation, differentiation, and diversification. Additionally, geographical and historical determinants influence urban farming. Thus, cultural heritage plays a larger role in Mediterranean regions compared to Germany or more Northern and Central European regions. The case studies show that economies of scope via diversification and differentiation are more important in metropolitan areas than economies of scale via low-cost specialisation. The latter option is the most common and mainstream farm path in rural areas offering expansion options in terms of land and livestock units, but urban influences force farmers in densely populated areas to fill business niches via adjustments and innovative business thinking.

Yet, low-cost specialisation also belongs in urban farming and is a business model for at least a few urban farms, such as those in the Seville region with its favourable conditions to exploit cost reduction strategies. Diversification is the most frequent business model detected in the case study regions, including diversifiers into agriculture, especially by health care institutions entering farming from outside the primary sector. This empirical work from Spain, Italy and Germany fits into scientific findings that UA has to specialise, differentiate or diversify - or to combine these alignments. Many farms investigated in this survey merge aspects of more than one business model. Merged business model concepts might be one way to reach sustainability under challenging urban conditions. Thus, it seems to be appropriate to conduct larger surveys to evaluate the business model approach, emphasising such merged business model concepts to a greater extent.

Methodologically, the strategic management template of the BMC permits researchers to analyse the organisation and performances of farms, both economically and socially. It also allows for the definition and comparison of key success factors, barriers, competitors and business ideas and innovations. In conclusion, this method seems appropriate for the analysis of urban farming businesses for future research agendas. Business-related studies on urban farming or more generally on urban agriculture, are rare, although they have become more common recently. Knowledge creation, discourses on methodological issues and learning from good practices, are relevant to leverage city-adjustments of farms to maintain their profitability and simultaneously to provide positive externalities for society and environment.

\section{Acknowledgement}

This article is based upon work from COST Action "Urban Agriculture Europe" (TD 1106), supported by COST (European Cooperation in Science and Technology). The authors would like to thank Prof. Frank Lohrberg and Prof. Lionalle Scazossi who have supported researchers as Chair and Vice-Chair of this Action.

\section{References}

ALONSO, W. (1964): Location and Land Use. Cambridge, Harvard University Press.

ANTROP, M. (2005): Why landscapes of the past are important for the future. Landscape and Urban Planning, 70(1-2): 21-34.

AUBRY, C., KEBIR, L. (2013): Shortening food supply chains: A means for maintaining agriculture close to urban areas? The case of the French metropolitan area of Paris. Food Policy, 41: 85-93.

BAILEY, A., WILLIAMS, N., PALMER, M., GEERING, R. (2000): The farmer as a service provider: The demand for agricultural commodities and equine services. Agricultural Systems, 66: 191-204.

BEAUCHESNE, A., BRYANT, C. (1999): Agriculture and Innovation in the Urban Fringe: The Case of Organic Farming in Quebec, Canada. Tijdschrift voor Economische en Social Geografie, 90(3): 320-328.

BOONS, F., LÜDEKE-FREUND, F. (2013): Business models for sustainable innovation: state-of-the-art and steps towards a research agenda. Journal of Cleaner Production, 45: 9-19.

BRINKLEY, C. R. (2012): Evaluating the benefits of PeriUrban Agriculture. Journal of Planning Literature, 27(3): 259-269.

BRYANT, C., SANCHEZ, N. C., DELUSCA, K., DAOUDA, O., SARR, A. (2013): Metropolitan Vulnerability and Strategic Roles for Peri-urban Agricultural Territories in the Context of Climate Change and Vulnerability. Cuadernos de Geografia, 22(2): 55-68.

BUCIEGA, A., PITARCH, M. D., ESPARCIA, J. (2009): The context of rural-urban relationships in Finland, France, Hungary, the Netherlands and Spain. Journal of Environmental Policy and Planning, 11(1): 9-27. 
BUSCK, A. G., KRISTENSEN, S. P., PRAESTHOLM, S. REENBERG, A., PRIMDAHL, J. (2006): Land system changes in the context of urbanization: Examples from the peri-urban area of Greater Copenhagen. Geografisk Tidsskrift (Danish Journal of Geography), 106(2): 21-34.

DUPRAS, J., PARCERISAS, L., BRENNER, J. (2016): Using ecosystem services valuation to measure the economic impacts of land-use changes on the Spanish Mediterranean coast (El Maresme, 1850-2010). Regional Environmental Change, 16(4): 1075-1088.

ELGÅKER, H., WILTON, B. (2008): Horse farms as a factor for development and innovation in the urban-rural fringe with examples from Europe and Northern America. Forest \& Landscape Working Papers, 27. Copenhagen, University of Copenhagen.

FAO (2007): Profitability and sustainability of urban and peri-urban agriculture. Agricultural Management, Marketing and Finance. Rome, FAO.

FERGUSON, D. T. (2014): Night-soil and the 'Great Divergence': Human waste, the urban economy, and economic productivity, 1500-1900. Journal of Global History, 9(3): 379-402.

GARDNER, B. L. (1994): Commercial Agriculture in Metropolitan Areas: Economics and Regulatory Issues. Agricultural and Resource Economics Review, 23(1): 100-109.

GANGULY, S., KUJAC, P., LEONARD, M., WAGNER, J., WORTHINGTON, Z. (2011): Lively' Hood Farm. Strategy Plan. [cit. 12.3.2014]. Available at: http://www. sfenvironment.org/sites/default/files/fliers/files/sfe_uf_ strategy_plan.pdf

HEDIN, D. I. (2015): The business models of commercial urban farming in developed countries. Masters thesis. Swedish University of Agricultural Sciences. Department of Economics. Uppsala. [cit. 20.9.2016]. Available at: http://stud.epsilon.slu.se/8523/1/Hedin_D_151001.pdf

HEIMLICH, R. E., BARNARD, C. H. (1992): Agricultural Adaption to Urbanization: Farm Types in Northeast Metropolitan Areas. Northeastern journal of agricultural and resource economics, 21(1): 50-60.

HENRIKSEN, K., BJERRE, M., ALMASI, A. M., DAMGAARD-GRANN, E. (2012): Green Business Model Innovation. Conceptualization report. Nordic Innovation Publication. [cit. 12.3.2014]. Available at: http://www.nordicinnovation.org/Global/_Publications/ Reports/2012/2012_16\%20Green\%20Business\%20 Model\%20Innovation_Conceptualization\%20report_ web.pdf

HOUSTON, P. (2005): Re-valuing the Fringe: Some Findings on the Value of Agricultural Production in Australia's Peri-Urban Regions. Geographical Research, 43(2): 209-223.

KORTHALS ALTES, W. K., VAN RIJ, E. (2013): Planning the horticultural sector: Managing greenhouse sprawl in the Netherlands. Land Use Policy, 31(1): 486-497.

LIU, S. (2015): Business Characteristics and Business Model Classification in Urban Agriculture. Master thesis. Wageningen, Wageningen University and Research Centre. (February $2^{\text {nd }}, 2016$ )
LOHRBERG, F. (2010): Urbane Agrarlandschaften. In: Valentin, D., [ed.]: Wiederkehr der Landschaft (pp. 24-33). Berlin, Jovis.

LOHRBERG, F., TIMPE, A. (2011): Urbane Agrikultur. Neue Formen der Primärproduktion in der Stadt. Planerin, 5: $35-37$.

LOHRBERG, F., LIČKA, L., SCAZZOSI, L., TIMPE, A. [eds.] (2016): Urban agriculture Europe. Berlin, Jovis.

LOVELL, S. T. (2010): Multifunctional Urban Agriculture for Sustainable Land Use Planning in the United States. Sustainability 2010, 2(8): 2499-2522.

LUNDY, M., AMREIN, A., HURTADO, J. J., BECX, G., ZAMIEROWSKI, N., RODRÍGUEZ, F., MOSQUERA, E. E. (2014): LINK methodology: a participatory guide to business models that link smallholders to markets. Version 2.0. Cali, Centro Internacional de Agricultura Tropical (CIAT).

MCCLINTOCK N. (2014): Radical, reformist, and gardenvariety neoliberal: coming to terms with urban agriculture's contradiction. Local Environment, 19(2): 147-171.

MOUGEOT, L. J. A. (2000): Urban Agriculture: definition, presence, potentials and risks, and policy challenges. Cities Feeding People Series Report 31. Ottawa, International Development Research Centre (IDCR).

NATIONALE FEDERATIE STADSGERICHTE LANDBOUW (2013): Stadsboeren in Nederland. Professionalisering van de stadsgerichte landbouw. [cit. 13.3.2014]. Available at: http://www.vanbergenkolpa.nl/ postbus/website/NFSL.pdf

NGUYEN, T., TRUONG, M. (2013): The Business Plan. Case: Organic Farm in Ho Chi Minh City, Vietnam. Bachelor's Thesis in International Business. Lahti University of Applied Sciences. [cit. 12.3.2014]. Available at: http://www.theseus.fi/bitstream/handle/10024/64452/ Nguyen_Tri.pdf?sequence $=2$

OPITZ, I., BERGES, R., PIORR, A., KRIKSER, T. (2016): Contributing to food security in urban areas: Differences between urban agriculture and peri-urban agriculture in the Global North. Agriculture and Human Values, 33(2): 341-358.

OSTERWALDER, A., PIGNEUR, Y. (2010): Business Model Generation. [cit. 11.3.2014]. Available at: http://www. businessmodelgeneration.com

PÉRON, J. Y., GEOFFRIAU, E. (2007): Characteristics and Sustainable Development of Peri-Urban Vegetable Production in Europe. ISHS Acta Horticulture, International Symposium on Horticultural Plants in Urban and Peri-Urban Life, 62: 159-170.

PIORR, A., RAVETZ, J., TOSICS, I. (2011): Peri-Urbanisation in Europe: Towards European Policies to Sustain UrbanRural Futures; Forest and Landscape, Copenhagen, University of Copenhagen.

PÖLLING, B., LORLEBERG, W., ORSINI, F., MAGREFI, F., HOEKSTRA, F., RENTING, H., ACCORSI, M. (2015): Business models in Urban Agriculture - answering cost pressures and societal needs. Conference Paper. Agriculture in an Urbanizing Society. September 2015. Rome, Italy. 
PÖLLING, B. (2016): Comparison of Farm Structures, Success Factors, Obstacles, Clients' Expectations and Policy Wishes of Urban Farming's Main Business Models in North RhineWestphalia, Germany. Sustainability, 8(5): 446.

PÖLLING, B., MERGENTHALER, M., LORLEBERG, W. (2016): Professional urban agriculture and its characteristic business models in Metropolis Ruhr, Germany. Land Use Policy, 58: 366-379.

PRAIN, G., DE ZEEUW, H. (2007): Enhancing technical, organizational and institutional innovation in urban agriculture. Urban Agriculture Magazine (RUAF), 19: 9-15.

QUETIER, F. F., GORDON, I. J. (2003): "Horticulture": How important a land use change in Scotland? Scottish Geographical Journal, 119: 153-159.

SIEBERT, R., DOSCH, A., VOLGMANN, A. (2009): Arbeit und Einkommen im ländlichen Raum. Chancen durch Diversifizierung. Ministerium für Infrastruktur und Landwirtschaft des Landes Brandenburg (Hrsg., October $7^{\text {th }} 2014$ ).

SIMON-ROJO, M. et al. (2015): From urban food gardening to urban farming. In: Lohrberg, F., Licka, L., Scazzosi, L., Timpe, A. [eds.]: Urban Agriculture Europe (pp. 22-28), Berlin, Jovis.

TORQUATI, B., TANCINI, C., PAFFARINI, C., ILLUMINATI, R. (2015): Empirical survey on business models of kindergarten farms. Agricultural and Food Economics, 3(1): 25.

VAN DER SCHANS, J. W. (2010): Urban Agriculture in the Netherlands. Urban Agriculture Magazine, 24: 40-42.

VAN DER SCHANS, J. W. (2015): Business models urban agriculture (online) [cit. 1.1.2016]. Available at: https:// www.wageningenur.nl/upload_mm/f/3/6/fb858e59-
2190-46d9-8fe7-f293efd8c0a8_MFL_Business\%20 models\%20urban\%20agriculture.\%20Juni\%20 2015\%20Small.pdf

VAN DER SCHANS, J. W. et al. (2016): It Is a Business! Business Models in Urban Agriculture. In: Lohrberg, F., Licka, L., Scazzosi, L., Timpe, A. [eds.]: Urban Agriculture Europe (pp. 82-91). Berlin, Jovis.

VOGL, C. R., AXMANN, P., VOGL-LUKASSER, B. (2003): Urban organic farming in Austria with the concept of Selbsternte ("self-harvest"): An agronomic and socioeconomic analysis. Renewable Agriculture and Food Systems, 19(2): 67-79.

WISKERKE, J. S. C. (2009): On regions lost and regions regained: Reflections on the alternative food geography and sustainable regional development. International Planning Studies, 14(4): 369-387.

YOKOHARI, M., BROWN, R. D., TAKEUCHI, K. (1994): A framework for the conservation of rural ecological landscapes in the urban fringe area in Japan. Landscape and Urban Planning, 29: 103-116.

ZASADA, I. (2011): Multifunctional peri-urban agricultureA review of societal demand and the provision of goods and services by farming. Land Use Policy, 28(4): 639-648.

ZASADA, I., FERTNER, C., PIORR, A., NIELSEN, T. S. (2011): Peri-urbanization and multifunctional adaptation of agriculture around Copenhagen. Geografisk Tidsskrift (Danish Journal of Geography), 111(1): 59-72.

ZASADA, I., BERGES, R., HILGENDORF, J., PIORR, A. (2013): Horsekeeping and the peri-urban development in the Berlin Metropolitan Region. Journal of Land Use Science, 8(2): 199-214.

\section{Please cite this article as:}

PÖLLING, B., PRADOS, M. R., TORQUATI, B. M., GIACCHÈ, G., RECASENS, X., PAFFARINI, C., ALFRANCA, O., LORLEBERG, W. (2017): Business models in urban farming: A comparative analysis of case studies from Spain, Italy and Germany. Moravian Geographical Reports, 25(3): 166-180. Doi: 10.1515/mgr-2017-0015. 